\title{
Usulan Perancangan Key Performance Indicator (KPI) dengan Konsep Green HRM menggunakan Perspektif Performance Prism dan Metode AHP pada Waris Cafe
}

\author{
Winda Ayu Kinanti ${ }^{1 *}$, Nunung Nurhasanah ${ }^{1}$ \\ ${ }^{1}$ Program Studi Teknik Industri, Fakultas Sains dan Teknologi, Universitas Al Azhar Indonesia, \\ Komplek Masjid Agung Al Azhar, Jalan Sisingamangaraja, Kebayoran Baru, Jakarta Selatan 12110
}

Penulis untuk Korespondensi/E-mail: kinanti.windaa@gmail.com

Abstrak - Dalam keberlangsungan suatu kinerja perusahaan, pentingnya memiliki satuan baku dalam pengukuran kinerja perusahaan. Jika perusahaan tidak memiliki pengukuran kinerja, hal tersebut ternyata berdampak buruk bagi perusahaan karena tidak adanya bahan evaluasi untuk memperbaiki kinerja perusahaan terutama di bagian sumber daya manusia. Pada penelitian ini, dilakukan usulan perancangan KPI pada restoran Waris Café dengan menerapkan konsep Green HRM. Bertujuan untuk merancang kinerja perusahaan dan turut serta menjaga keseimbangan lingkungan dengan melibatkan seluruh stakeholder restoran. Berdasarkan hasil wawancara dan diskusi dengan pakar, didapatkan 75 KPI secara keseluruhan yang terdiri dari tiap 5 stakeholder, dimana dalam tiap stakeholder memiliki 5 perspektif performance prism, dan dalam tiap 1 perspektif memiliki masing-masing 3 KPI. Dengan menggunakan metode Analytical Hierarchy Process yang dibantu dengan software Super Decisions, didapatkan hasil bobot kepentingan stakeholder terpilih yaitu investor dengan bobot 30,38\%. Bobot KPI pada tiap hirarki yaitu, stakeholder investor sebesar 0,1056 terdapat pada KPI peningkatan persentase pendapatan, pemasok sebesar 0,0993 terdapat pada KPI mekanisme quality control yang dilakukan diperketat, pelanggan sebesar 0,1047 terdapat pada KPI penentuan kualitas makanan yang disajikan, karyawan sebesar 0,1349 terdapat pada KPI efektivitas pemberian rewards dan compensation $10 \%$ dari pendapatan, regulator sebesar 0,1154 terdapat pada KPI mematuhi aturan yang ditetapkan pemerintah dalam proses bisnis yang dijalankan.

Abstract - In the sustainability of a company's performance, the importance of having a standard unit in measuring company performance. If the company does not have performance measurements, it turns out to have a bad impact for the company because there is no evaluation material to improve company performance, especially in the human resources section. In this study, the proposed design of KPI in Waris Café restaurant by applying the Green HRM concept. Aiming to not only design company performance, but also to maintain environmental balance by involving all restaurant stakeholders. Based on the results of interviews and discussions with experts, obtained 75 KPIs as a whole consisting of every 5 stakeholders, where each stakeholder has 5 performance prism perspectives, and in each 1 perspective each has 3 KPIs. By using the Analytical Hierarchy Process method which is assisted by the Super Decisions software, the result of the weighting of the interests of the selected stakeholders is investors with a weight of $30.38 \%$. KPI weights in each hierarchy namely, stakeholder investors amounted to 0.1056 contained in KPIs increased percentage of income, suppliers amounted to 0.0993 contained in KPI quality control mechanisms were carried out tightened, customers amounted to 0.1047 contained in KPI determining the quality of food served, employees amounted to 0.1349 contained in KPI effectiveness granting rewards and compensation of $10 \%$ of revenue, the regulator of 0.1154 found in KPI complies with the rules set by the government in the business processes carried out.

Keywords - Performance indicator, Performance prism, Green human resources management, Analytical Hierarchy Process 


\section{PENDAHULUAN}

$\mathrm{P}$ enilaian kinerja suatu perusahaan adalah sesuatu yang penting sebagai parameter penilaian apakah perusahaan tersebut berjalan dengan baik atau tidak. Untuk mengetahui kinerja yang dimiliki maka perlu dilakukan pengukuran kinerja [1]. Pengukuran kinerja merupakan hal yang penting dalam menilai keberhasilan suatu perusahaan menjalankan proses bisnisnya. Pentingnya pengukuran kinerja untuk menganalisis perbedaan antara kinerja secara aktual maupun yang diharapkan (target perusahaan). Dengan mengetahui perbandingan tersebut, sebuah perusahaan dapat mengukur penyimpangan yang terjadi dan dapat merencanakan implementasi perbaikan [2]. Salah satu pengukuran manajemen kinerja adalah performance prism, merupakan kerangka pengukuran manajemen kinerja yang inovatif dengan memperhatikan beberapa sisi komponen terhadap kebutuhan dan keinginan para stakeholder [3]. Keunggulan performance prism, yaitu melibatkan semua stakeholder organisasi, sehingga penerapan metode ini diharapkan dapat menunjang kelangsungan hidup perusahaan dalam jangka panjang akan lebih terjamin. Secara prinsip, meliputi investor, pelanggan, karyawan, supplier, dan masyarakat [4].

Seiring berjalannya waktu, masyarakat mulai menyadari bahwa pertumbuhan ekonomi tidak hanya membahayakan lingkungan namun juga merugikan masyarakat. Untuk merespon hal tersebut, perusahaan dari berbagai macam sektor mencoba mengembangkan produk-produk maupun proses-proses yang dapat mengurangi dampak negatif industri terhadap lingkungan [5]. Di Indonesia, kesadaran organisasi dalam megimplementasikan konsep ramah lingkungan dalam kegiatan bekerja setiap hari masih rendah. Konsep ramah lingkungn tidak hanya dilakukan dengan membuat produk ramah lingkungan, akan tetapi dapat dilakukan dengan cara setiap organisasi mengimplementasi konsep ramah lingkungan kedalam fungsi-fungsi manajemen sumber daya manusia melalui penerapan Green Human Resource Management (Green HRM). Green HRM bertujuan untuk meningkatan moral karyawan terhadap pengelolaan lingkungan yang baik [6]. Restoran adalah organisasi yang memiliki potensi yang cukup besar dalam menerapkan sistem yang bersifat ramah lingkungan. Salah satu wujud untuk menjalankan upaya ramah lingkungan dalam proses bisnis sebuah restoran yaitu dengan mengimplementasikan Green Practices dalam kegiatan operasionalnya [7].

Penelitian ini dilakukan di Waris Café, yang merupakan usaha dibidang restoran. Dalam pelaksanaannya, Waris cafe tidak memiliki satuan baku dalam pengukuran kinerja perusahaan. Berdasarkan hal tersebut maka peneliti membuat usulan perancangan Key Performance Indicator (KPI) menggunakan Performance Prism dengan implementasi Green HRM yang diperoleh dari brainstorming dengan para pakar dan studi literatur. Pada penentuan bobot tiap hierarki digunakan metode Analytical Hierarchy Process (AHP) dengan bantuan software Super Decision.

\section{METODE}

Penelitian ini terdiri dari tiga tahap yaitu tahap pertama identifikasi kebutuhan stakeholder berbasis perspektif performance prism dengan implementasi Green HRM melalui studi literatur dan wawancara serta validasi ke pakar. Pada prinsipnya metode performance prism dikerjakan dalam dua arah yaitu dengan mempertimbangkan kebutuhan dan keinginan (needs and wants) dari semua stakeholder serta mengidentifikasikan kontribusi dari stakeholder terhadap organisasi tersebut [8].

Tahap kedua dilakukan perancangan KPI yang teridentifikasi tersebut, dan yang terakhir adalah tahap pembobotan kepentingan stakeholder dan KPI dimana dilakukan penyebaran kuisioner berpasangan [9].

Tahap ketiga adalah penghitungan hasil kuisioner dengan metode AHP melalui software Super Decision.

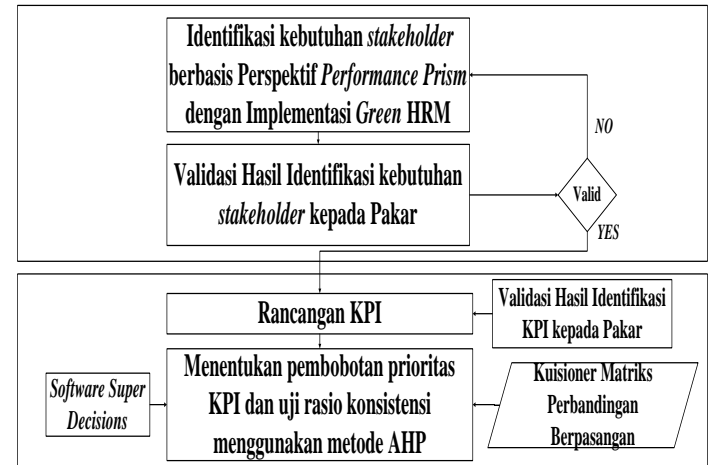

Gambar 1. Flowchart penelitian tahap perancangan kpi 


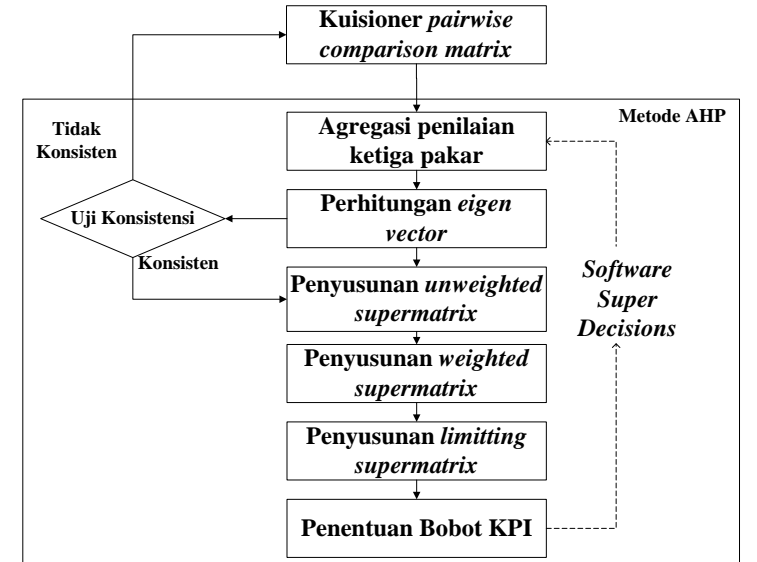

Gambar 2. Flowchart algoritma AHP dengan Software Super Decisions

Tahap pertama pada perhitungan algortiman AHP dengan software super decision adalah menginput data hasil agregasi terhadap penilaian dari ketiga pakar yang terpilih ke dalam software berdasarkan setiap kuesioner yang ada. Formulasi pengolahan matematis dalam melakukan agregasi penilaian pakar dilakukan dengan Geometric Mean. Adapun rumus dari perhitungan Geometric Mean [10] adalah sebagai berikut:

$G M=(P 1 \times P 2 \times \ldots \times P n) 1 / \mathrm{n}$

Tahap kedua yaitu melakukan pemilihan alternatif strategi berdasarkan bobot terbesar. Penggunaan software membantu dalam mensistesa hasil pembobotan eigen vector dengan melakukan perhitungan pada data hasil penilaian skala yang didapatkan dari hasil input kuesioner matriks perbandingan berpasangan yang telah diagregasi sejumlah pakar. Adapun perhitungan manual untuk menentukan nilai eigen vector dilakukan dengan pemangkatan (pangkat dua, atau perkalian sendiri) setiap pairwise comparison matrix. Berdasarkan tahapan pengolahan ini, dihasilkan nilai berupa bobot atau nilai eigen yang nantinya akan membantu dalam menentukan prioritas bobot dari faktor-faktor yang berpengaruh serta bobot prioritas pada alternatif.

Tahap ketiga ialah melakukan uji konsistensi pada hasil bobot yang didapatkan dari agregasi pakar. Uji konsistensi dilakukan untuk mengetahui tingkat kesesuaian data yang dihasilkan yang merefleksikan validasi terhadap hasil bobot yang telah diberikan oleh ketiga pakar. Sehingga analisa tersebut didapatkan kuesioner apa saja yang konsisten dan tidak konsisten, agar dapat pengkajian kembali mengenai kuesioner yang tidak konsisten. Hasil bobot dapat dinyatakan konsisten apabila
Consistency Ratio lebih kecil atau sama dengan dari 0,1 dan akan dinyatakan tidak konsisten jika nilai Consistency Ratio lebih besar dari 0,1.

Tahapan terakhir ialah melakukan formulasi supermatrix dari mulai perhitungan dalam pembuatan unweighted supermatrix (nilai eigen vector yang terpilih akan dijadikan input super matrix dan dimana setiap kolomnya akan ditotalkan), perhitungan dalam pembuatan weighted supermatrix (secara manual perhitungan dapat dilakukan dengan mengalikan proporsi (total kolom dibagi nilai per kolom), dengan nilainya sendiri di tiap kolom), dan melakukan perhitungan limiting supermatrix. Hasil pembobotan dari limiting supermatrix (hasil ini diperoleh dengan memangkatkan weighted supermatrix dengan $2 \mathrm{k}+1$, dimana $\mathrm{k}$ merupakan suatu bilangan yang besar), yang pada akhirnya dapat dijadikan prioritas KPI.

\section{Pengumpulan Data}

Data - data yang dikumpulkan adalah hasil identifikasi 13 kebutuhan stakeholder melalui perspektif performance prism dengan implementasi Green HRM, perancangan indikator kinerja berbasis performance prism, hasil kuesioner AHP berupa bobot penilaian pakar untuk kepentingan stakeholder dan KPI. Berdasarkan hasil brainstorming dengan 3 pakar, dapat dilakukan perancangan indikator kinerja berbasis performance prism dengan menguraikan KPI dari setiap perspektif performance prism yang telah ditetapkan sebelumnya. Selain itu, penentuan KPI juga mengacu pada data sekunder yang terkait penelitian yakni laporan kinerja dan keuangan Waris Café sebagai acuan dalam melihat pencapaian restoran. Tiap 5 perspektif performance prism terhubung dengan 5 stakeholder restoran yang masing-masing memiliki 15 KPI. Total KPI pada seluruh stakeholder adalah $75 \mathrm{KPI}$.

Berdasarkan hasil penetapan Key Performance Indicators (KPI) dapat dideskripsikan dalam persepketif performance prism sebagai berikut:

A. KPI pada perspektif stakeholder Satisfaction:

1. (I1) Transparansi laporan perusahaan dengan pihak investor melalui task sharing

2. (I2) Tingkat kelancaran komunikasi melalui investor relationship

3. (I3) Dukungan aktif praktik Green HRM dalam manajemen lingkungan

4. (C1) Persentase tingkat kepuasan pelanggan

5. (C2) Persentase komplain pelanggan

6. (C3) Persentase makanan terbuang 
7. (E1) Persentase karyawan nyaman dengan lingkungan kerja

8. (E2) Ruang dan lingkungan yang terawat dan hemat energi

9. (E3) Tingkat retensi karyawan meningkat

10. (S1) Persentase pembayaran secara tepat waktu

11. (S2) Persentase jumlah pembelian

12. (S3) Tingkat jaminan kerjasama yang berkesinambungan

13. (R1) Tingkat kepuasan regulator dalam proses bisnis yang dijalankan

14. (R2) Mematuhi aturan yang ditetapkan pemerintah pada proses bisnis

15. (R3) Jumlah lapangan kerja yang tersedia pada restoran

B. KPI pada perspektif strategy

1. (I4) Persentase pengendalian biaya operasional

2. (I5) Persentase peningkatan pendapatan

3. (I6) Tingkat kepuasan kerjasama antara perusahaan dengan investor dalam mendukung praktik Green HRM

4. (C4) Pengembangan fasilitas ramah lingkungan

5. (C5) Frekuensi promo tiap libur nasional

6. (C6) Persentase keluhan yang dilayani

7. (E4) Perbaikan kinerja dan loyalitas karyawan dengan konsep Green Work Life

8. (E5) Mengadakan training karyawan mengenai manajemen lingkungan

9. (E6) Persentase kebijakan manajemen lingkungan yang dipatuhi

10. (S4) Pengontrolan pemenuhan kebutuhan terkait lingkungan (zero waste)

11. (S5) Persentase kewajiban yang dipenuhi oleh pemasok

12. (S6) Maksimasi penggunaan kembali, pemulihan dan daur ulang sumber daya (resource)

13. (R4) Jumlah masyarakat yang turut serta diberdayakan

14. (R5) Menjalankan kebijakan sesuai komitmen etika lingkungan

15. (R6) Rasio komitmen jangka panjang mengenai implementasi praktik Green HRM dalam praktik bisnis

C. KPI pada perspektif process

1. (I7) Perencanaan keuangan sesuai kebutuhan

2. (I8) Persentase peningkatan margin

3. (I9) Komitmen investor jangka panjang

4. (C7) Pengemasan makanan menggunakan bahan ramah lingkungan

5. (C8) Tingkat layanan kepada pelanggan

6. (C9) Tingkat perbaikan kualitas bahan makanan yang digunakan
7. (E7) Komunikasi interen dengan penerapan green whistleblowing atau help lines

8. (E8) Frekuensi pemberian pelatihan karyawan

9. (E9) Efektivitas pemberian rewards dan compensation $10 \%$ dari pendapatan

10. (S7) Pembayaran tepat waktu dan rekap berkas pembayaran secara online

11. (S8) Pengoptimalan sistem pengadaan bahan baku

12. (S9) Mekanisme quality control yang dilakukan diperketat

13. (R7) Frekuensi pelaksanaan pelatihan

14. (R8) Mengembangkan sistem disiplin progresif

15. (R9) Jumlah perekrutan calon karyawan

D. KPI pada perspektif capability

1. (I10) Tingkat akurasi laporan data keuangan perusahaan

2. (I11) Pengendalian keuangan dari jumlah keuangan yang defisit

3. (I12) Tingkat kepuasan investor

4. (C10) Pengelolaan hubungan baik dengan pelanggan

5. (C11) Penentuan kualitas makanan yang dihasilkan

6. (C12) Persentase terhadap customer acquisition

7. (E10) Menyertakan kompetensi ramah lingkungan dalam spesifikasi pekerjaan

8. (E11) Ketersediaan kelengkapan fasilitas pendukung kerja dalam praktik Green HRM

9. (E12) Evaluasi prestasi kinerja karyawan sesuai dengan kriteria perilaku ramah lingkungan

10. (S10) Minimalisasi keterlambatan pengiriman bahan baku

11. (S11) Kelancaran komunikasi antara pemasok dengan perusahaan

12. (S12) Informasi stock bahan pemesanan

13. (R10) Persentase kebijakan yang diaplikasikan

14. (R11) Membangun citra positif di masyarakat

15. (R12) Frekuensi pelaksanaan program CSR

E. KPI pada perspektif stakeholder contribution

1. (I13) Penetapan jumlah investasi untuk operasional dalam penerapan praktik Green HRM

2. (I14) Pengumpulan berkas keuangan secara online

3. (I15) Evaluasi saran dan masukan

4. (C13) Tingkat persentase keikutsertaan pelanggan dalam praktik Green HRM

5. (C14) Tingkat retensi pelanggan

6. (C15) Persentase tingkat keluhan dari pelanggan

7. (E13) Menerapkan inisatif inovasi lingkungan dengan menerapkan prinsip retrieve energy 
8. (E14) Peningkatan kedisiplinan karyawan

9. (E15) Menerapkan standar ISO 14000

10. (S13) Tingkat kesesuaian barang yang dipesan

11. (S14) Pemenuhan kebutuhan bahan dengan standar kualitas yang sudah ditetapkan

12. (S15) Efisiensi pengendalian biaya dan waktu pemesanan bahan baku

13. (R13) Persentase pembinaan mengenai deep ecology dan manajemen lingkungan

14. (R14) Persentase regulasi yang menguntungkan dari bisnis dengan penerapan praktik Green HRM dan manajemen lingkungan

15. (R15) Frekuensi pelaksanaan penyuluhan dan informasi

\section{Pengolahan Data}

\section{AHP (Analytical Hierarchy Process)}

Tujuan AHP untuk mengetahui tingkat kepentingan dari pihak-pihak yang berkepentingan dalam permasalahan terhadap elemen. Struktur hierarki memberikan indikasi bahwa dalam proses pembuatan model keputusan dengan AHP, kriteria yang sudah dihasilkan dari penyusunan kriteria dan tatanan hirarki mempunyai bobot yang tidak sama sesuai dengan tingkat kontribusi masing-masing kriteria terhadap tujuan yang ingin dicapai [1].

Langkah awal pada perhitungan dengan metode AHP [8] yaitu pembuatan hierarki dengan tujuan mengetahui bobot kepentingan pada stakeholder dan KPI dari masing-masing stakeholder:

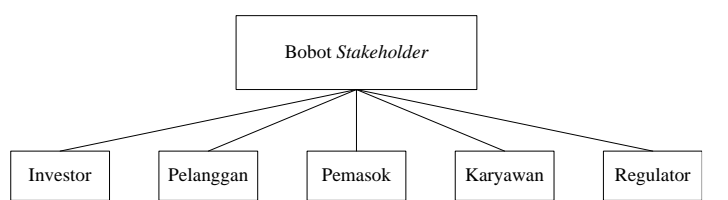

Gambar 3. Hierarki AHP pada bobot Stakeholder

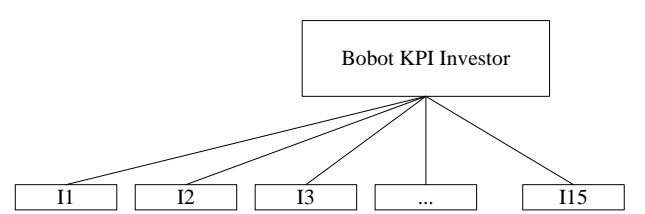

Gambar 4. Hierarki AHP pada bobot Investor

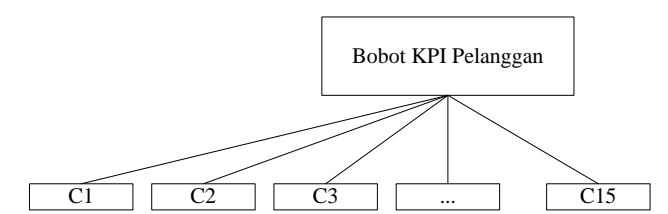

Gambar 5. Hierarki AHP pada bobot Pelanggan

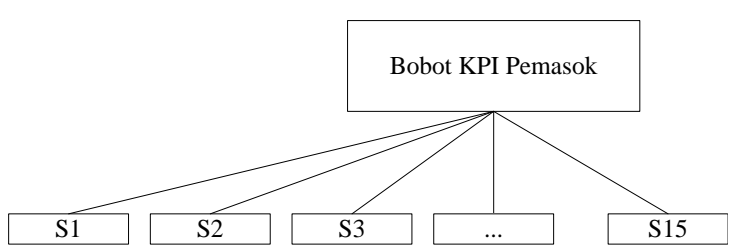

Gambar 6. Hierarki AHP pada bobot Pemasok

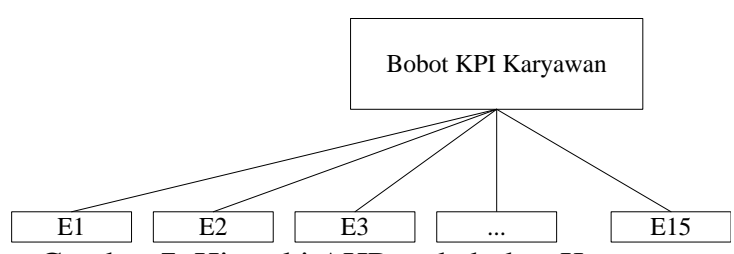

Gambar 7. Hierarki AHP pada bobot Karyawan

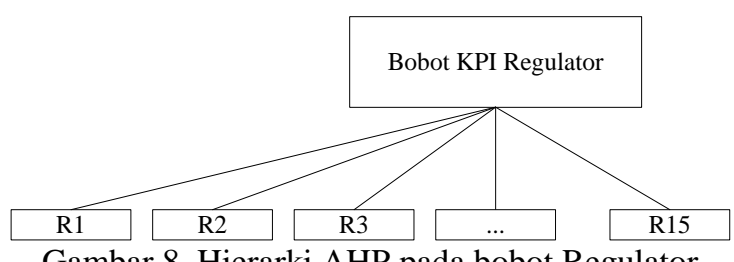

Gambar 8. Hierarki AHP pada bobot Regulator

\section{HASIL DAN PEMBAHASAN}

Berikut dilampirkan hasil pembobotan untuk bobot prioritas stakeholder dan KPI dari tiap masing masing stakeholder:

Tabel 1. Hierarki pembobotan prioritas stakeholder

\begin{tabular}{lcc}
\hline Stakeholder & $\begin{array}{c}\text { Bobot } \\
\text { Stakeholder }\end{array}$ & Prioritas \\
\hline Investor & 0,2881 & 1 \\
Karyawan & 0,1692 & 3 \\
Pelanggan & 0,2546 & 2 \\
Pemasok & 0,144 & 5 \\
Regulator & 0,144 & 4 \\
\hline Total & & \\
Bobot & 1 & \\
\hline
\end{tabular}

Berdasarkan hasil pengolahan data menggunakan software Super Decisions, didapatkan bahwa investor memiliki prioritas kepentingan paling tinggi dengan bobot sebesar 0,2881. Adanya hal ini sangat mencerminkan kondisi aktual restoran, dimana berdasarkan hasil diskusi dan wawancara, memberikan emphasis (menitik beratkan) yang besar terhadap investor. Hal ini disebabkan karena pentingnya peran investor dalam perencanaan modal untuk penerapan KPI dengan praktik Green HRM. 
Tabel 2. Hasil rekapitulasi pembobotan kpi dari stakeholder investor

\begin{tabular}{|c|c|c|c|c|}
\hline Stakeholder & Perspektif & & KPI & $\begin{array}{c}\text { Bobot } \\
\text { Perspektif }\end{array}$ \\
\hline \multirow{15}{*}{ 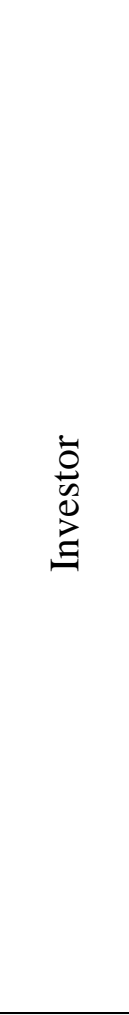 } & \multirow{3}{*}{ Kepuasan } & I1 & $\begin{array}{l}\text { Transparasi laporan perusahaan } \\
\text { dengan pihak investor melalui } \\
\text { task sharing }\end{array}$ & 0,0737 \\
\hline & & I2 & $\begin{array}{l}\text { Tingkat kelancaran komunikasi } \\
\text { melalui investor relationship }\end{array}$ & 0,0543 \\
\hline & & $\mathrm{I} 3$ & $\begin{array}{l}\text { Dukungan aktif praktik Green } \\
\text { HRM dalam manajemen } \\
\text { lingkungan }\end{array}$ & 0,0533 \\
\hline & \multirow{3}{*}{ Strategi } & I4 & $\begin{array}{l}\text { Persentase pengendalian biaya } \\
\text { operasional }\end{array}$ & 0,0587 \\
\hline & & I5 & $\begin{array}{l}\text { Peningkatan persentase } \\
\text { pendapatan }\end{array}$ & 0,1056 \\
\hline & & I6 & $\begin{array}{l}\text { Tingkat kepuasan kerjasama } \\
\text { antara perusahaan dengan } \\
\text { investor dalam mendukung } \\
\text { praktik Green HRM }\end{array}$ & 0,0471 \\
\hline & \multirow{3}{*}{ Proses } & I7 & $\begin{array}{l}\text { Perencanaan keuangan sesuai } \\
\text { dengan kebutuhan }\end{array}$ & 0,0691 \\
\hline & & I8 & $\begin{array}{l}\text { Pengembalian investasi tepat } \\
\text { waktu }\end{array}$ & 0,1048 \\
\hline & & I9 & $\begin{array}{l}\text { Komitmen investor jangka } \\
\text { panjang }\end{array}$ & 0,0643 \\
\hline & \multirow{3}{*}{ Kapabilitas } & $\mathrm{I} 10$ & $\begin{array}{l}\text { Tingkat akurasi laporan data } \\
\text { keuangan perusahaan }\end{array}$ & 0,0718 \\
\hline & & I11 & $\begin{array}{l}\text { Pengendalian keuangan dari } \\
\text { jumlah yang defisit }\end{array}$ & 0,089 \\
\hline & & I12 & Tingkat kepuasan investor & 0,0649 \\
\hline & \multirow{3}{*}{ Kontribusi } & I13 & $\begin{array}{l}\text { Penetapan jumlah investasi untuk } \\
\text { operasional dlam penerpan praktik } \\
\text { Green HRM }\end{array}$ & 0,0492 \\
\hline & & I14 & $\begin{array}{l}\text { Pengumpulan berkas keuangan } \\
\text { secara online }\end{array}$ & 0,031 \\
\hline & & $\mathrm{I} 15$ & Evaluasi saran dan masukan & 0,0612 \\
\hline \multicolumn{4}{|c|}{ Total Bobot } & 1 \\
\hline
\end{tabular}

Tabel 3. Hasil rekapitulasi pembobotan kpi dari stakeholder pelanggan

\begin{tabular}{|c|c|c|c|c|}
\hline Stakeholder & Perspektif & & KPI & $\begin{array}{c}\text { Bobot } \\
\text { Perspektif }\end{array}$ \\
\hline \multirow{15}{*}{ 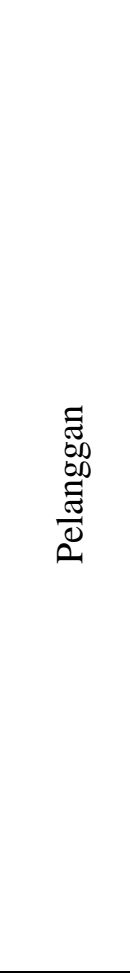 } & \multirow{3}{*}{ Kepuasan } & $\mathrm{C} 1$ & $\begin{array}{l}\text { Presentase tingkat kepuasan } \\
\text { pelanggan }\end{array}$ & 0,0897 \\
\hline & & $\mathrm{C} 2$ & Presentase komplain pelanggan & 0,0607 \\
\hline & & $\mathrm{C} 3$ & Presentase makanan terbuang & 0,0403 \\
\hline & \multirow{3}{*}{ Strategi } & $\mathrm{C} 4$ & $\begin{array}{l}\text { Pengembangan fasilitas ramah } \\
\text { lingkungan }\end{array}$ & 0,0376 \\
\hline & & $\mathrm{C} 5$ & $\begin{array}{l}\text { Frekuensi promo tiap libur } \\
\text { nasional }\end{array}$ & 0,0673 \\
\hline & & C6 & Presentase keluhan yang dilayani & 0,0498 \\
\hline & \multirow{3}{*}{ Proses } & $\mathrm{C} 7$ & $\begin{array}{l}\text { Pengemasan makanan } \\
\text { menggunakan bahan ramah } \\
\text { lingkungan }\end{array}$ & 0,0523 \\
\hline & & $\mathrm{C} 8$ & $\begin{array}{l}\text { Tingkat layanan kepada } \\
\text { pelanggan }\end{array}$ & 0,1003 \\
\hline & & C9 & $\begin{array}{l}\text { Tingkat perbaikan kualitas bahan } \\
\text { makanan yang digunakan }\end{array}$ & 0,1003 \\
\hline & \multirow{3}{*}{ Kapabilitas } & $\mathrm{C} 10$ & $\begin{array}{l}\text { Pengelolaan hubungan baik } \\
\text { dengan pelanggan }\end{array}$ & 0,0872 \\
\hline & & $\mathrm{C} 11$ & $\begin{array}{l}\text { Penentuan kualitas makanan yang } \\
\text { disajikan }\end{array}$ & 0,1047 \\
\hline & & $\mathrm{C} 12$ & $\begin{array}{l}\text { Presentase terhadap customer } \\
\text { acquistion }\end{array}$ & 0,0498 \\
\hline & \multirow{3}{*}{ Kontribusi } & $\mathrm{C} 13$ & $\begin{array}{l}\text { Tingkat persentase keikutsertaan } \\
\text { pelanggan dalam praktik Green } \\
\text { HRM }\end{array}$ & 0,0498 \\
\hline & & $\mathrm{C} 14$ & Tingkat retensi pelanggan & 0,0498 \\
\hline & & $\mathrm{C} 15$ & $\begin{array}{l}\text { Persentase tingkat keluhan dari } \\
\text { pelanggan }\end{array}$ & 0,0607 \\
\hline \multicolumn{4}{|c|}{ Total Bobot } & 1 \\
\hline
\end{tabular}

Tabel 4. Hasil rekapitulasi pembobotan kpi dari stakeholder karyawan

\begin{tabular}{|c|c|c|c|c|}
\hline Stakeholder & Perspektif & & KPI & $\begin{array}{c}\text { Bobot } \\
\text { Perspektif }\end{array}$ \\
\hline \multirow{15}{*}{ 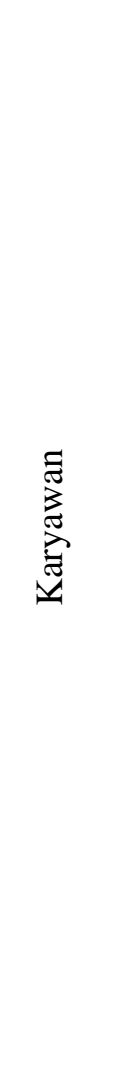 } & \multirow{3}{*}{ Kepuasan } & E1 & $\begin{array}{l}\text { Presentase karyawan nyaman } \\
\text { dengan lingkungan kerja }\end{array}$ & 0,0502 \\
\hline & & $\mathrm{E} 2$ & $\begin{array}{l}\text { Ruang dan lingkungan yang } \\
\text { terawat dan hemat energi }\end{array}$ & 0,053 \\
\hline & & E3 & $\begin{array}{l}\text { Tingkat retensi karyawan } \\
\text { meningkat }\end{array}$ & 0,0503 \\
\hline & \multirow{3}{*}{ Strategi } & E4 & $\begin{array}{l}\text { Perbaikan kinerja dan loyalitas } \\
\text { karyawan dengan konsep Green } \\
\text { Work Life }\end{array}$ & 0,0544 \\
\hline & & E5 & $\begin{array}{l}\text { Mengadakan Training karyawan } \\
\text { mengenai manajemen lingkungan }\end{array}$ & 0,0661 \\
\hline & & E6 & $\begin{array}{l}\text { Persentase kbijakan manajemen } \\
\text { lingkungan yang dipatuhi }\end{array}$ & 0,0379 \\
\hline & \multirow{3}{*}{ Proses } & E7 & $\begin{array}{l}\text { Komunikasi Interen dengan } \\
\text { penerapan green whistleblowing } \\
\text { atau help lines }\end{array}$ & 0,0338 \\
\hline & & E8 & $\begin{array}{l}\text { Frekuensi pemberian pelatihan } \\
\text { karyawan }\end{array}$ & 0,0602 \\
\hline & & E9 & $\begin{array}{l}\text { Efektivitas pemberian rewards } \\
\text { dan compensation } 10 \% \text { dari } \\
\text { pendapatan }\end{array}$ & 0,1349 \\
\hline & \multirow{3}{*}{ Kapabilitas } & E10 & $\begin{array}{l}\text { Menyertakan kompetensi ramah } \\
\text { lingkungan dalam spesifikasi } \\
\text { pekerjaan }\end{array}$ & 0,0768 \\
\hline & & E11 & $\begin{array}{l}\text { Ketersediaan kelengkapan } \\
\text { fasilitas pendukung kerja dalam } \\
\text { praktik Green HRM }\end{array}$ & 0,0822 \\
\hline & & E12 & $\begin{array}{l}\text { Evaluasi prestasi kinerja karyawan } \\
\text { sesuai dengan kriteria perilaku } \\
\text { ramah lingkungan }\end{array}$ & 0,0684 \\
\hline & \multirow{3}{*}{ Kontribusi } & E13 & $\begin{array}{l}\text { Menerapkan inisiatif inovasi } \\
\text { lingkungan dengan menerapkan } \\
\text { prinsip retrieve energy }\end{array}$ & 0,0847 \\
\hline & & E14 & $\begin{array}{l}\text { Peningkatan kedisiplinan } \\
\text { karyawan }\end{array}$ & 0,0941 \\
\hline & & E15 & Menerapkan standar ISO 14000 & 0,0529 \\
\hline \multicolumn{4}{|c|}{ Total Bobot } & 1 \\
\hline
\end{tabular}

Tabel 5. Hasil rekapitulasi pembobotan kpi dari stakeholder pemasok

\begin{tabular}{|c|c|c|c|c|}
\hline Stakeholder & Perspektif & & KPI & $\begin{array}{c}\text { Bobot } \\
\text { Perspektif }\end{array}$ \\
\hline \multirow{15}{*}{ 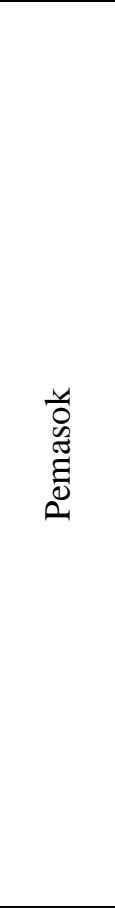 } & \multirow{3}{*}{ Kepuasan } & S1 & $\begin{array}{l}\text { Persentase pembayaran secara } \\
\text { tepat waktu }\end{array}$ & 0,0442 \\
\hline & & S2 & Persentase jumlah pembelian & 0,0399 \\
\hline & & S3 & $\begin{array}{l}\text { Tingkat jaminan kerjasama yang } \\
\text { berkesinambungan }\end{array}$ & 0,0723 \\
\hline & \multirow{3}{*}{ Strategi } & S4 & $\begin{array}{l}\text { Pengontrolan pemenuhan } \\
\text { kebutuhan terkait lingkungan } \\
\text { (zero waste) }\end{array}$ & 0,0518 \\
\hline & & S5 & $\begin{array}{l}\text { Persentase kewajiban yang } \\
\text { dipenuhi oleh pemasok }\end{array}$ & 0,055 \\
\hline & & S6 & $\begin{array}{l}\text { Maksimasi penggunaan kembali, } \\
\text { pemulihan dan daur ulang sumber } \\
\text { daya (resource) }\end{array}$ & 0,0731 \\
\hline & \multirow{3}{*}{ Proses } & S7 & $\begin{array}{l}\text { Pembayaran tepat waktu dan } \\
\text { rekap berkas pembayaran secara } \\
\text { online }\end{array}$ & 0,0479 \\
\hline & & S8 & $\begin{array}{l}\text { Pengoptimalan sistem pengadaan } \\
\text { bahan baku }\end{array}$ & 0,0699 \\
\hline & & S9 & $\begin{array}{l}\text { Mekanisme quality control yang } \\
\text { dilakukan diperketat }\end{array}$ & 0,0933 \\
\hline & \multirow{3}{*}{ Kapabilitas } & S10 & $\begin{array}{l}\text { Minimalisasi keterlambatan } \\
\text { pengiriman bahan baku }\end{array}$ & 0,066 \\
\hline & & S11 & $\begin{array}{l}\text { Kelancaran komunikasi antara } \\
\text { pemasok dengan perusahaan }\end{array}$ & 0,078 \\
\hline & & $\mathrm{S} 12$ & Informasi stock bahan pemesanan & 0,0624 \\
\hline & \multirow{3}{*}{ Kontribusi } & S13 & $\begin{array}{l}\text { Tingkat kesesuaian barang yang } \\
\text { dipesan }\end{array}$ & 0,0827 \\
\hline & & S14 & $\begin{array}{l}\text { Pemenuhan kebutuhan bahan } \\
\text { dengan standar kualitas yang } \\
\text { suah ditetapkan }\end{array}$ & 0,0689 \\
\hline & & S15 & $\begin{array}{l}\text { Efesiensi pengendalian biaya dan } \\
\text { waktu }\end{array}$ & 0,0885 \\
\hline \multicolumn{4}{|c|}{ Total Bobot } & 1 \\
\hline
\end{tabular}


Tabel 6. Hasil rekapitulasi pembobotan kpi dari stakeholder regulator

\begin{tabular}{|c|c|c|c|c|}
\hline Stakeholder & Perspektif & & KPI & $\begin{array}{c}\text { Bobot } \\
\text { Perspektif }\end{array}$ \\
\hline \multirow{15}{*}{ 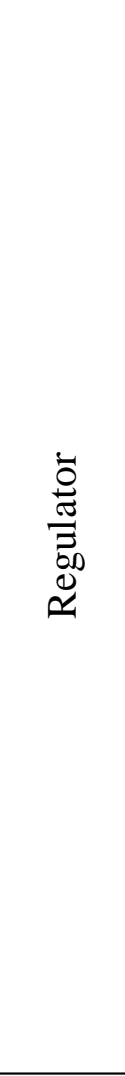 } & \multirow{3}{*}{ Kepuasan } & R1 & $\begin{array}{l}\text { Tingkat kepuasan regulator dalam } \\
\text { proses bisnis yang dijalankan }\end{array}$ & 0,0634 \\
\hline & & $\mathrm{R} 2$ & $\begin{array}{l}\text { Mematuhi aturan yang ditetapkan } \\
\text { pemerintah pada proses bisnis }\end{array}$ & 0,1154 \\
\hline & & $\mathrm{R} 3$ & $\begin{array}{l}\text { Jumlah lapangan kerja yang } \\
\text { tersedia pada restoran }\end{array}$ & 0,1033 \\
\hline & \multirow{3}{*}{ Strategi } & R4 & $\begin{array}{l}\text { Jumlah masyarakat yang turut } \\
\text { serta diberdayakan }\end{array}$ & 0,0722 \\
\hline & & R5 & $\begin{array}{l}\text { Menjalankan kebijakan sesuai } \\
\text { komitmen etika lingkungan }\end{array}$ & 0,0396 \\
\hline & & R6 & $\begin{array}{l}\text { Rasio komitmen jangka panjang } \\
\text { mengenai implementasi praktik } \\
\text { Green HRM dalam praktik bisnis }\end{array}$ & 0,057 \\
\hline & \multirow{3}{*}{ Proses } & R7 & Frekuensi pelaks anaan pelatihan & 0,0766 \\
\hline & & R8 & $\begin{array}{l}\text { Mengembangkan sistem disiplin } \\
\text { progresif }\end{array}$ & 0,0591 \\
\hline & & R9 & $\begin{array}{l}\text { Jumlah perekrutan calon } \\
\text { karyawan }\end{array}$ & 0,0711 \\
\hline & \multirow{3}{*}{ Kapabilitas } & R10 & $\begin{array}{l}\text { Presentase kebijakan yang di } \\
\text { aplikasikan }\end{array}$ & 0,0862 \\
\hline & & R11 & $\begin{array}{l}\text { Membangun citra positif di } \\
\text { masyarakat }\end{array}$ & 0,0588 \\
\hline & & $\mathrm{R} 12$ & $\begin{array}{l}\text { Frekuensi pelaksanaan program } \\
\text { CSR }\end{array}$ & 0,0399 \\
\hline & \multirow{3}{*}{ Kontribusi } & R13 & $\begin{array}{l}\text { Presentase pembinaan mengenai } \\
\text { deep ecology dan manajemen } \\
\text { lingkungan }\end{array}$ & 0,0508 \\
\hline & & R14 & $\begin{array}{l}\text { Persentase regulasi yang } \\
\text { menguntungkan dari bisnis } \\
\text { dengan penerapan praktik Green } \\
\text { HRM dan manajemen lingkungan }\end{array}$ & 0,062 \\
\hline & & R15 & $\begin{array}{l}\text { Frekuensi pelaksanaan } \\
\text { penyuluhan dan informasi }\end{array}$ & 0,0446 \\
\hline \multicolumn{4}{|c|}{ Total Bobot } & 1 \\
\hline
\end{tabular}

Berdasarkan hasil pengolahan data menggunakan AHP dengan bantuan software Super Decisions, didapatkan hasil pembobotan yang telah dinormalisasi. Pada stakeholder investor, bobot tertinggi dimiliki oleh variabel KPI terkait peningkatan persentase pendapatan dengan nilai bobot 0,1056; dalam praktik Green HRM adanya komitmen manajemen terhadap lingkungan berhubungan positif dengan komitmen organisasi, sehingga perusahaan dapat menjadi lebih kuat ketika mendapat dukungan dari para stakeholder. Pada stakeholder pelanggan, bobot prioritas KPI tertinggi terkait penentuan kualitas makanan yang disajikan restoran dengan nilai bobot 0,1047 ; dalam praktik Green HRM adanya pengelolaan peningkatan mutu pelayanan yang ditawarkan dengan penerapan produk dan jasa pada prinsip manajemen lingkungan, dengan tujuan mengembangkan dan memberikan jasa yang tidak memiliki dampak lingkungan yang tidak semestinya dan aman digunakan, serta memiliki tingkat efisiensi dalam konsumsi dari energi dan sumber daya alam dan yang dapat didaur ulang.
Pada stakeholder karyawan, bobot prioritas tertinggi dihasilkan pada variabel KPI terkait efektivitas pemberian rewards dan compensation 10\% dari pendapatan dengan bobot sebesar 0,1349, dalam praktik Green HRM adanya implementasi pemberian insentif keuangan kepada karyawan yang berperilaku ramah lingkungan dalam mencapai goals pekerjaannya, sedangkan insentif nonkeuangan juga diperlukan berupa pujian dan pengakuan karyawan yang berperilaku ramah lingkungan. Jika karyawan melakukan pelanggaran maka perusahaan dapat menerapkan disiplin progresif kepada karyawan.

Pada stakeholder regulator, bobot prioritas tertinggi dihasilkan pada variabel KPI terkait mematuhi aturan yang ditetapkan pemerintah pada proses bisnis dengan nilai bobot 0,1154 , dalam praktik Green HRM bahwa pentingnya penerapan dari aturan yang ditetapkan pemerintah dalam proses bisnis yang dilaksanakan termasuk untuk mendukung pemerintah dalam menjaga keseimbangan lingkungan. Sementara itu, pada stakeholder pemasok, bobot prioritas tertinggi dihasilkan pada variabel KPI terkait mekanisme quality control yang dilakukan diperketat dengan nilai bobot 0,0933; dalam praktik Green HRM adanya penerapan diperketatnya quality control pada bahan baku yang digunakan untuk mengurangi limbah yang ada, sehingga meminimasi cacat produk dan meningkatkan biaya pemesanan.

\section{KESIMPULAN}

Berdasarkan pengumpulan data dan hasil analisis dari pengolahan data yang telah dilakukan, maka diperoleh kesimpulan identifikasi kebutuhan stakeholder melalui perspektif performance prism pada Waris Café dengan implementasi Green HRM, masing-masing terdapat 13 kebutuhan pada perspektif stakeholder satisfaction, stakeholder contribution dan process. Sedangkan pada perspektif strategy dan capability terdapat 12 kebutuhan stakeholder.

Berdasarkan hasil kebutuhan stakeholder yang telah didentifikasi, dapat diinterpretasikan bahwa terdapat 75 KPI secara keseluruhan yang terdiri dari tiap 5 stakeholder masing-masing memiliki 15 KPI, dimana dalam tiap stakeholder memiliki 5 perspektif performance prism, dan dalam tiap 1 perspektif memiliki masing-masing $3 \mathrm{KPI}$. 
Hasil dari pengolahan data dengan menggunakan AHP menggunakan software Super Decisions, pada level 1 yaitu didapatkan hasil bobot prioritas stakeholder yang tertinggi adalah investor, dengan bobot sebesar 0,3039. Sedangkan pada level 2 yaitu bobot prioritas perancangan KPI yang tertinggi pada KPI I5 dengan stakeholder investor dan bobot yang diperoleh sebesar 0,034068. KPI tersebut adalah melakukan peningkatan persentase pendapatan. Dalam praktik Green HRM, hal tersebut perlu adanya komitmen manajemen terhadap lingkungan berhubungan positif dengan komitmen organisasi, sehingga perusahaan dapat menjadi lebih kuat ketika mendapat dukungan dari para stakeholder.

Berdasarkan kesimpulan penelitian yang telah dibuat, maka terdapat beberapa saran yakni:

1. Hasil rancangan KPI dengan perspektif performance prism diharapkan mampu diterapkan pada restoran Waris Cafe sebagai bahan pertimbangan untuk implementasi dalam mengevaluasi kinerja stakeholder Waris Cafe secara komprehensif

2. Untuk penelitian selanjutnya dalam implementasi hasil rancangan KPI, sebaiknya evaluasi kinerja dilakukan dengan bantuan aplikasi agar lebih mudah dalam proses perhitungan yang ditetapkan.

3. Untuk penelitian selanjutnya, diharapkan dapat mengkaji lebih dalam pembuatan kuesioner karena hal tersebut sangat berpengaruh baik pada proses pengambilan data maupun konsistensi penilaian sehingga berdampak pada tingkat kepercayaan hasil penelitian. Apabila penilaian pakar tidak konsisten, dapat dilakukan pergantian pakar atau perubahan kalimat pertanyaan namun dengan makna yang sama.

\section{UCAPAN TERIMA KASIH}

Penyelesaian Tugas Akhir ini tidak terlepas dari dukungan, bantuan, bimbingan, serta motivasi yang berarti dari berbagai pihak, untuk itu pada kesempatan kali ini penulis ingin mengucapkan banyak terimakasih kepada:

1. Keluarga besar yakni orang tua, kakek dan nenek serta adik penulis yang telah memberikan doa, semangat, dan memfasilitasi penulis dalam menyelesaikan Laporan Tugas Akhir ini.

2. Ibu Nunung Nurhasanah S.T., M.Si, selaku dosen pembimbing yang memfasilitasi dan selalu memberikan motivasi juga arahan yang sangat membantu baik dalam pengerjaan laporan ini.
3. Randy Rachmady selaku pemilik Waris Café yang telah memberikan izin dalam proses pengambilan data, dan Noviandy selaku Manajer yang telah bersedia membantu penulis dalam pengambilan data.

4. Teman-teman Teknik Industri angkatan 2015 yang penul is sayangi khususnya, Astri Ayudia, Alika Ratnamirah, Azyyati, Rafidah, Melinda, Putri Laila dan Farra Nabila selaku "Tim Hore" yang setia memberikan dukungan kepada penulis.

5. Bagus Adi Sukmodewo, yang telah membantu dan memberikan motivasi kepada penulis.

6. Seluruh jajaran sivitas akademika Fakultas Sains dan Teknologi Program Studi Teknik Industri yang telah membantu dalam penyelesaian Tugas Akhir ini.

\section{REFERENSI}

[1] Ahmad and L. L. Salomon, "Pengukuran Kinerja Perusahaan dengan Metode Integrated Performance Measurement System (IPMS) dan OMAX (Studi Kasus: PT APSM)," in Seminar Nasional Mesin dan Industri (SNMI9), Bali, 2014.

[2] C. A. Purnomo and Y. Hadi, "Pengukuran Kinerja UMKM Menggunakan Performance Prism," Spektrum Industri, vol. 15, no. 2, pp. 121 -136, 2017.

[3] A. D. Neely, C. Adams and M. Kennerley, The Performance Prism, UK: Cranfield School of Management, 2000.

[4] Adianto, M. A. Saryatmo and A. S. Gunawan, "Analisis Pengukuran Kinerja Perusahaan Dengan Metode Performance Prism dan Scoring Objective Matrix (OMAX) pada PT BPAS," SINERGI, vol. 18 , no. 2, pp. 61 - 70, 2014.

[5] F. Schubert, J. Kandampully, S. David and A. Kralj, Exploring Consumer Perceptions of Green Restaurants in the US, Colombus: The Ohio State University, 2010.

[6] H. H. D. N. P. Opatha and A. A. Arulrajah, "Green Human Resource Management: Simplified General Reflection," Internasional Business Research, vol. 7, no. 8, pp. 101-112, 2014.

[7] R Johnson, "Organisational motivations for going green for profitability versus sustainability," Bussiness Review, vol. 13, no. $1,2009$. 
[8] H. Prastawa, D. Pujotomo, A. Arvianto and F. Khoirunnisa, "Sistem Pengukuran Kinerja Dengan Metode Performance Prism (Studi Kasus di Rumah Sakit Islam Sultan Agung Semarang)," TEKNIK, vol. 32, no. 1, 2011.
[9] T. L. Saaty, "How to Make a Decision: The Analytic Hierarchy Process, Institute for Operations," Research and the Management Science, vol. 24, no. 6, 1994.

[10] M. C. Fleming and J. G. Nellis, Principles of Applied Statistic, New York: Routledge, 1994. 